\title{
Al Mujib Natural Reserve in Jordan: - Towards an Assessment for Sustainable Ecotourism Management Plan Utilizing Spatial Documentation
}

\author{
Naif A.Haddad ${ }^{1, *}$, Sharaf A. Al-kheder ${ }^{2}$, Leen A. Fakhoury ${ }^{3}$ \\ ${ }^{1}$ Department of Conservation Science, Queen Rania's Institute of Tourism and Heritage, Hashemite University, P.O. Box 3034, Amman \\ 11181, Jordan \\ ${ }^{2}$ Department of Civil Engineering, Faculty of Engineering \& Applied Sciences, ALHOSN University, Abu Dhabi, UAE \\ ${ }^{3}$ School of Architecture and Built Environment, German Jordanian University, Amman, Jordan \\ *Corresponding Author: naifh@hu.edu.jo
}

Copyright $(\underset{0}{2013}$ Horizon Research Publishing All rights reserved.

\begin{abstract}
Using Al Mujib wildlife natural reserve in Jordan as a case study (one of the largest reserves in Jordan established in 1987, and the lowest elevation of about $-400 \mathrm{~m}$ on earth), this paper, is an attempt to address assisting and developing ecotourism sustainability to initiate the role of planning and management using spatial documentation in nature reserves, focusing on the existing situation, the cultural significance, the constraints, the threats and other planning and management aspects that the reserve is facing. The paper attempts to develop a platform for government officials, scholars, co-management practitioners and key stakeholders to discuss the issue of sustainability enhancement and management of the reserve, in relation to a GIS monitoring data base.
\end{abstract}

Keywords GIS; Spatial Analysis, Monitoring, Site Management, Ecological Sustainability

\section{Introduction}

Nature reserves are vital to protect and conserve the natural biodiversity, especially the rare flora and fauna, from different natural and man-made threats affecting their existence and sustainability. Actually, the changes in the landscape, mainly due to the fast growing anthropogenic activities; lack of water resources; and climatic changes [17], since the world war II has affected the biodiversity system which has recorded a steep decline in natural resources $[7,21,30]$.

This emphasizes the need to establish more nature reserves and to adopt sustainable management and spatial planning techniques in and nearby such reserves, such as the 1986 National Spatial Plan (NSP) adopted by Slovenia[11] ,to protect the remaining natural heritage.

Establishing such reserves provides attractive ecotourism destinations. However, tourism involved in the creation of an experience based on attraction, meanwhile ecotourism, is defined as "responsible travel to natural areas that conserves the environment and improves the well-being of local people"[26]. Ecotourism strategy, according to the Australian Commission on National is defined as "nature-based tourism that involves education and interpretation of the natural environment and is managed to be ecologically sustainable". Adopting a sustainable development approach, defined as "development which meets the needs of the present without compromising the ability of future generations to meet their needs" [31], will ensure preserving such natural areas from any external or internal threats.

Worldwide, tourists spend more time and money during their stay, the majority ( $82 \%$ ) tends to be higher graduates with wildlife interests [19]. However, making ecotourism a positive economic and environmental tool in developing countries, conservation of the biological heritage requires strategies and policies that promote responsible nature tourism development, broad-based and active local participation in its benefits. Eco-tourism demands a holistic approach to travel, one in which its participants strive to respect, learn about and benefit both the local environment and local communities.

Jordan, as a Mediterranean country, where desert (Badiya) composes a large portion of its area $(\sim 70 \%)$, starts paying more attention to natural reserves. This is clear through the increasing interest in establishing more and more reserves. On the other hand, whilst spatial documentation using GIS had been used in many environmental applications in Jordan, there is no use of such powerful system in the field of natural reserves management.

This paper shall discuss and evaluate the existing situation, the cultural significance of Al Mujib nature reserve in Jordan (as one of the largest reserves in Jordan, and the lowest reserve on earth about $-400 \mathrm{~m}$ ), and other planning and 
management aspects including the threats and the development needs the reserve is facing, while assessing the role of GIS spatial analysis in creating, analyzing and monitoring a digital spatial database for the reserve to document the natural biodiversity system elements.

\section{Assessment of Al Mujib Reserve: Natural and Cultural Significance}

Jordan enjoys different types of climate with different seasons for tourism; for example, the Dead Sea, Al Mujib natural reserve and the Baptism Site are considered to be winter destinations because they have a moderate climate, recreation/sport, and therapeutic properties as well as religious tourisms. However, the cultural significance and core attractive factors of AlMujib Natural Reserve can be defined in relation to four main issues: it's existence as landmark, eco- site, historical and archaeological site, and its ecotourism activities.

\subsection{Its Existence as Landmark}

$\mathrm{Al}$ Mujib natural reserve is the lowest reserve on the planet located at the western, middle part, side of Jordan at $35^{\circ} 48^{\prime}$ East $31^{\circ} 28^{\prime}$ North central coordinates [8], on the eastern coast of the Dead Sea, which is considered as an important tourism destination (Figure 1). It has a total area of about 212 $\mathrm{km}^{2}$ with an extremely variable topographical altitude ranging from $-400 \mathrm{~m}$ (at Dead Sea area) to $800 \mathrm{~m}$ at the mountainous area creating marvelous scenery at the reserve[22].

\subsection{Its Existence as Eco-Site}

The natural attractions of the reserve's topography covers a wide spectrum of natural features such as rocky mountains, deep valleys, sandstone cliffs and waterfall 20 meters in height, that offers a variety in nature and wildlife and is a hotspot for eco- and adventure tourism. The reserve contains a number of water streams flowing throughout the year and its water system is composed of three large catchments: Wadi Mujib, Wadi Hidan and Wadi Zarka Ma'in [27]. The Reserve is a rich biodiversity area containing a wide variety of flora and fauna of great value.

Over than 412 species recorded through the RSCN survey carried out of which were 43 rare species, 67 medicinal plants, 12 poisonous species, 115 palatable plants and 22 edible species[27], 10 species of carnivores, and numerous species of permanent and migratory birds have been recorded [6]. Many medicinal plants of the Reserve are collected in spring and used all year long[16]. It's nice weather especially during winter and spring, compared to other areas in the country at this time of the year is highly favorable. Table 1 shows Al Mujib reserve major fauna and flora and related rare species.

Table 1. Al Mujib reserve major fauna and flora(Source: RSCN).

\begin{tabular}{|c|c|}
\hline $\begin{array}{c}\text { Fauna } \\
\text { Mammals } \\
24 \text { species have been recorded, ten of which are of } \\
\text { special importance. }\end{array}$ & $\begin{array}{c}\text { Nubian Ibex, striped hyena and Syrian wolf, Caracal cat, Golden Jackal Canis aureus, } \\
\text { Grey Wolf Canis lupus, Blanford's Fox Vulpes cana, Honey Badger Mellivora capensis, } \\
\text { Arabian Leopard Panthera pardus nimr, Capra ibex nubiana, Mountain Gazelle Gazella } \\
\text { gazelle and Rock Hyrax Procavia capensis. }\end{array}$ \\
\hline $\begin{array}{l}\text { Birds } \\
150 \text { species of birds have been recorded some of which } \\
\text { are of special importance on the international level }\end{array}$ & $\begin{array}{l}\text { Lesser Kestrel Falco naumanni and Imperial Eagle Aquila heliaca. Species of special } \\
\text { importance on the regional level include: Egyptian Vulture Neophron percnopterus, } \\
\text { Bonelli's Eagle Hieraaetus fasciatus, Griffon Vulture Gyps fulvus and Sooty Falcon } \\
\text { Falco concolor. Species of national importance include:CybrusWarblerSylvia } \\
\text { melanothorax and Ruppelle's warbler Sylvia rueppeli. }\end{array}$ \\
\hline $\begin{array}{c}\text { Reptiles } \\
\begin{array}{c}21 \text { species have been recorded, three of which are very } \\
\text { poisonous snakes }\end{array} \\
\end{array}$ & Walterinnesia aegyptia, Echis coloratus and Atractaspis engaddensis. \\
\hline Amphibians & Hyla savignyi , Bufo viridis, Rana bedriagae. \\
\hline Aquatic invertebrates & $\begin{array}{l}\text { 40-50 species have been recorded in Mujib Reserve, belonging to } 27 \text { families and five } \\
\text { different orders. }\end{array}$ \\
\hline Fish & Capeota damascina, Nemacheilus insignis and Garra rufa. \\
\hline Flora & $\begin{array}{c}\text { Kickxia judaica, Ophioglosum polyphyllum, Polygomum argyrocoleum, Withania } \\
\text { obtusifolia, Orchid and Palm }\end{array}$ \\
\hline
\end{tabular}




\subsection{Its Existence as Historical and Archaeological Site}

A small Nabataean temple has been identified in the rugged and isolated region of Al-Mujib Nature Reserve east of the Dead Sea, at Al-Riyashi north, probably dated to the first century BC/first century AD [5]. Hikers climb up to a historical fortification, on the way to the Ranger Station can also see the rock statue of Lot's Wife. According to the Bible she turned into a pillar of salt as she looked back on the cities Sodom and Gomorrah.

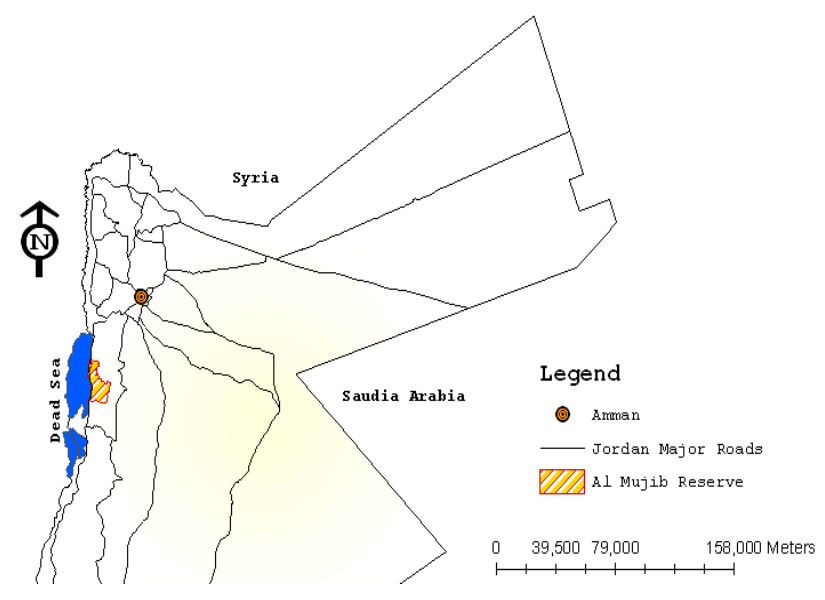

(a)

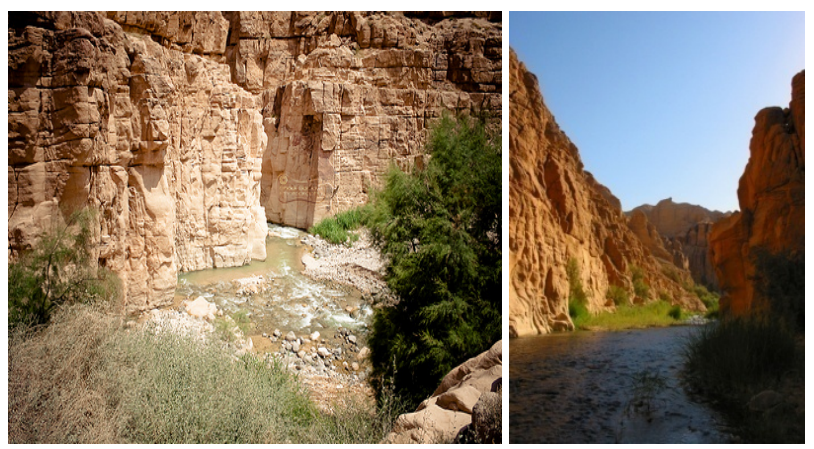

(b)

Figure 1. Al Mujib reserve geographic location (a) and scenery (b)

\section{4. Its Existence for Ecotourism Activities}

The reserve is equipped for ecotourism activities, especially for hiking through special trails. The reserve offers four major trails to visitors, two river trails and two dry land trails. The river trails are for adventure seekers. The Siq Trail leads into the main gorge of the Mujib River (the Siq). Visitors can also undertake the Mujib trail hike, a tough and exciting trail, which begins near the village of Fag'ua on the eastern edge of the nature reserve. Fag'ua is accessible from the famous King's Highway that leads out of Amman.
The following factors represents constraints for sustainable eco-tourism development in the reserve, where assessing the condition of such elements is crucial to identify the development needs.

Water scarcity: The main threat Al Mujib reserve is facing is represented in water shortage as water from the lower Mujib River had been diverted to supply the nearby tourist resorts [1]. The recent plans are to create more tourist resorts on the Dead Sea area; the many new implemented five stars hotels, and the many private apartments as in the case of Samarah Dead Sea Resort (2012-2013) are examples of this expansion. The shortage is getting more severe with the successive dry seasons in the area during the last few years. Such water scarcity adversely affects the fauna and flora of the reserve.

Grazing: Large scale grazing by livestock is still also one of the main land-use activities that are widespread in the region surrounding the study area. As for human activities around the study area, some private lands are used for agriculture. These lands are located on the eastern part of the study area around the main villages there [3].

According, to Birdlife International (2009)[8], threats' severity can be classified as follow:

\begin{tabular}{|c|c|}
\hline Agricultural intensification/expansion & Medium \\
\hline Burning of vegetation & Low \\
\hline Construction/impact of dyke/dam/barrage & Medium \\
\hline Disturbance to birds & Medium \\
\hline Infrastructure & Low \\
\hline Recreation/tourism & Low \\
\hline Unsustainable exploitation & High \\
\hline
\end{tabular}

Accessibility problem: Poor accessibility to the reserve makes it difficult for visitors, tourists and researchers to reach it [18], which also hampers the documentation, research, studies and development programs devoted to assess its current and future needs like the environmental conditions survey (temperature variations, salinity of soil, wind and so on) of the reserve, leading to developmental constraints, since the thematic patterns that could emerge from the research, may be useful for the reserve planners.

Lack of awareness: The lack of effective awareness programs for public focusing on development of effective cooperation to protect the reserves' biodiversity through continuous cleaning of the reserve, planting trees and encouraging the efforts of establishing different protection zones in the reserve, can also deteriorate the natural environment including vegetation, wildlife and landscape.

\section{Assessment of Role of Spatial documentation in Nature Reserves}

The importance of documentation may be undertaken as 
an aid to various activities like protection, conservation, preservation, identification, monitoring, interpretation, management of landscapes [13]. Documentation tools have undergone a major transformation over the last 20 years, primarily due to the advent of the PC and advancements in solid-state electronics. However, documentation is not only needed for proper conservation, preservation and site management, but foremost to raise public awareness. In fact, interactivity multi-media visualization production system can play a major role in interpretation, preservation, monitoring and management of natural reserves.

Spatial documentation and assessment of natural reserves using GIS, is a powerful technique for recording reserves status and its temporal status over time. GIS is an essential tool to generate spatiotemporal-monitoring maps with highresolutions showing the variability in the biodiversity system components in the reserve. Many countries in the world had used Geographic Information Systems (GIS) to develop natural reserve's digital mapping systems for documentation and assessment purposes such as the case of Singapore [23], Sabah Al Ahmad Natural Reserve in Kuwait [12], and the Tibet Nature Reserve[28].

GIS had been used also in identifying zones of priority for conservation and ecological restoration in the Sierra de la Laguna Biosphere Reserve, Mexico as integrated with interviews with residents and experts, and historical experience of management personnel of the area [9]. The ultimate goal of using GIS is to develop a Geo-database for the natural reserves network at various spatial scales to be used in different types of assessment, monitoring and policy studies similar to the ones developed for USA and Canada [10]. Though, GIS has the ability to document different natural spatial attributes in interactive databases and to present them in special maps with high-resolutions. In addition, it allows understanding and visualizing the spatial interrelationships between such elements. Meanwhile GIS had been used in many applications in Jordan, such as studying the environmental problem of the Dead Sea [2], and developing a GIS model for groundwater flow and heat transport in central Jordan [24], and in cultural heritage [4], however, no real use of such powerful system can be seen in the field of natural reserves documentation, which is considered a necessity to monitor the changes over time and the results of implementing certain policies.

\section{Towards an Integrated Management Plan of Al Mujib Reserve}

This section presents an analytical discussion and assessment of how al Mujib GIS-based documentation system can enhance the resave sustainability, and how to develop policies and regulations for a sustainable ecotourism management plan in Al Mujib Reserve.

\subsection{GIS-Based Documentation System for Enhancement of the Sustainability of Al Mujib Reserve}

This shall be illustrated through different analytical GIS layers of site location, exterior and interior accessibility analysis, topographic modeling, fauna and flora spatial distribution and other spatial analysis aspects.

For this purpose, some basic shapefiles are obtained from the RSCN, based on which other layers are created and analyzed, as in the case of topographic modeling that will be shown bellow. Such spatial layers that are created are the first step towards enhancing the reserve sustainability and assessment of planning development.

GIS gives the opportunity to explore the relationships between different spatial layers or within the same layer for the designed database such as in the querying process, 3D terrain modeling...etc.

All spatial features shown on these maps are linked to specific quantitative and qualitative "attributes" arranged in a certain data structure within the associated database. The GIS system presents a comprehensive database as a platform for government officials, co-management practitioners and key stakeholders, researchers, ecologists, planners, engineers and other people interested in studying the reserve spatially to discuss the management of Jordan natural reserves in general, and $\mathrm{Al}$ Mujib reserve specifically, in order to enhance extracting any possible rationale and policy, and legislative implications.

GIS-based spatial documentation is used to enhance the natural and man-made landscape within $\mathrm{Al}$ Mujib reserve boundary (geographic location, transportation network, contour map, 3D TIN continuous surface, 3D topography, surface digital elevation model "DEM", hiking trails, biodiversity system components "Fauna and Flora") Table 2.

Table 2. Conducted Al Mujib reserve analysis in GIS

\begin{tabular}{|c|c|c|}
\hline Map Title & Data Layer & Source \\
\hline $\begin{array}{l}\text { Country } \\
\text { Context }\end{array}$ & $\begin{array}{l}\text { Country Outlines, Amman City, } \\
\text { Roads Reserve Boundary }\end{array}$ & $\begin{array}{c}\text { ESRI - Arc GIS } \\
\text { Online Map } \\
\text { Services: } \\
\text { RSCN }\end{array}$ \\
\hline Local Context & $\begin{array}{c}\text { RSCN Boundary } \\
\text { TIN surface (Elevation in meters) }\end{array}$ & $\begin{array}{c}\text { RSCN } \\
\text { Boundary }\end{array}$ \\
\hline Transportation & $\begin{array}{c}\text { Transportation accessibility to and } \\
\text { within the reserve } \\
\text { Reserve Trails(major hiking } \\
\text { trails) }\end{array}$ & $\mathrm{RSCN}$ \\
\hline $\begin{array}{c}\text { Slope } \\
\text { Analysis }\end{array}$ & $\begin{array}{c}\text { Contours } \\
\text { Slope surface analysis }\end{array}$ & $\mathrm{RSCN}$ \\
\hline $\begin{array}{l}\text { Vegetation } \\
\text { Types }\end{array}$ & $\begin{array}{c}\text { Vegetation Types } \\
\text { Fauna, flora } \\
\text { Flora buffering example }(300 \mathrm{~m} \\
\text { protection area) }\end{array}$ & $\mathrm{RSCN}$ \\
\hline
\end{tabular}

\subsection{The need for Accessibility Enhancement}

Accessibility to the reserve from surrounding urban areas and mobility within the reserve are issues of concern. The first layer, presented in Figure 1, shows the spatial geographic location and extent of the reserve in Jordan and within the region. The layer presents as well the major road networks serving the region . 
The layer shows clearly the remote location of the reserve away from modern urban centers in Jordan, such as the capital Amman, where all the responsible body's for the reserve exist. This may impose more efforts on the authorities to follow-up and assess the reserves' landscape, temporal condition and other development services that the reserve might be in need of.

A GIS layer showing the part of the transportation network specific to the reserve is produced as shown in Figure 2. It's clear that the reserve is served with decent transportation network coming from a number of cities with the Dead Sea highway being the most suitable road to access the reserve.

In general, these roads pass nearby the reserve except for only one newly constructed road (shown in black color in Figure 2) that connects the Dead Sea highway with the reserve and intersects the reserve in its northern side. So, to enhance the accessibility level, there is a need to establish more roads to connect the highways surrounding the reserve with different parts of the reserve. A ring road that runs all the way around the reserve ensuring an enjoyable observatory for the reserve's landscape will be an attractive factor in any development policy.

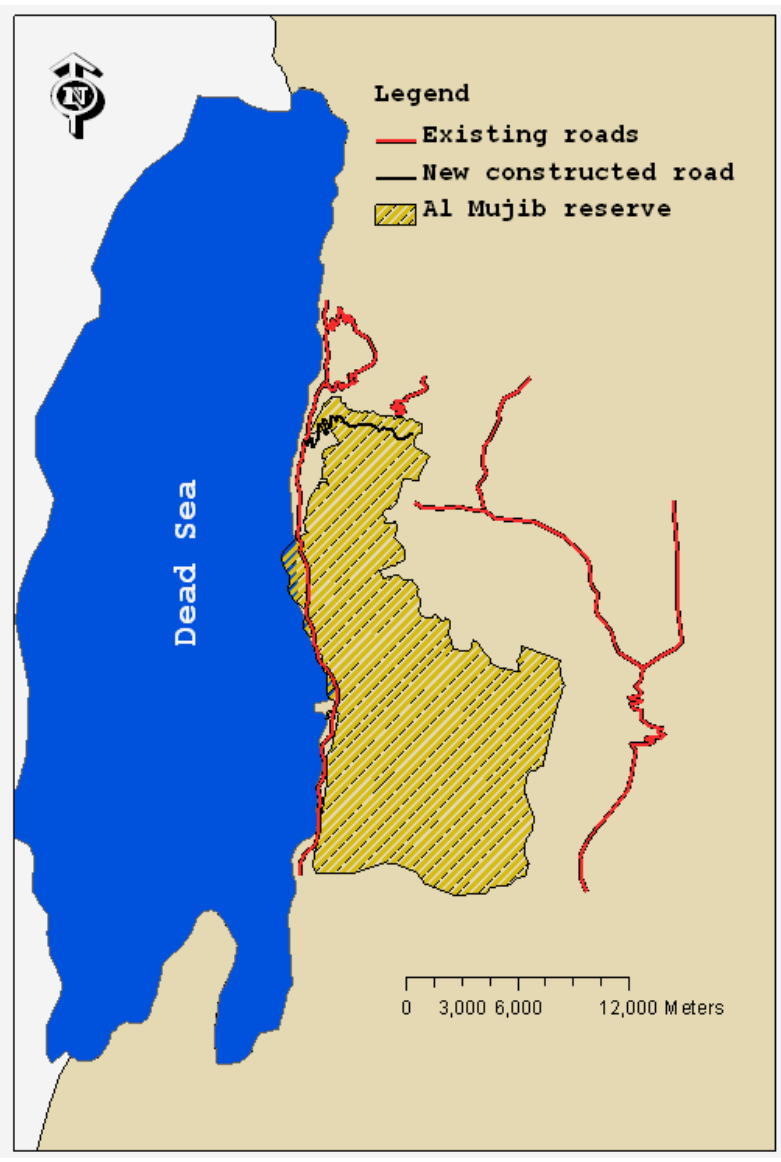

Figure 2. Transportation accessibility to and within the reserve

\subsection{Reserve's Landscape Topography Enhancement}

To more understand the reserve's landscape topography,
3D terrain modeling is performed in GIS that produces a number of spatial topographic layers. A contour map layer for the reserve (Figure 3), with a contour interval of 100 meters that was developed based on a detailed GPS survey of the reserve area, and was obtained from the Royal Society for the Conservation of Nature (RSCN). The contour map shows clearly the huge variability in the altitude within the reserve that ranges from -400 meters at its lowest level up to 800 meters for the highest altitude with an elevation difference of about 1200 meters.

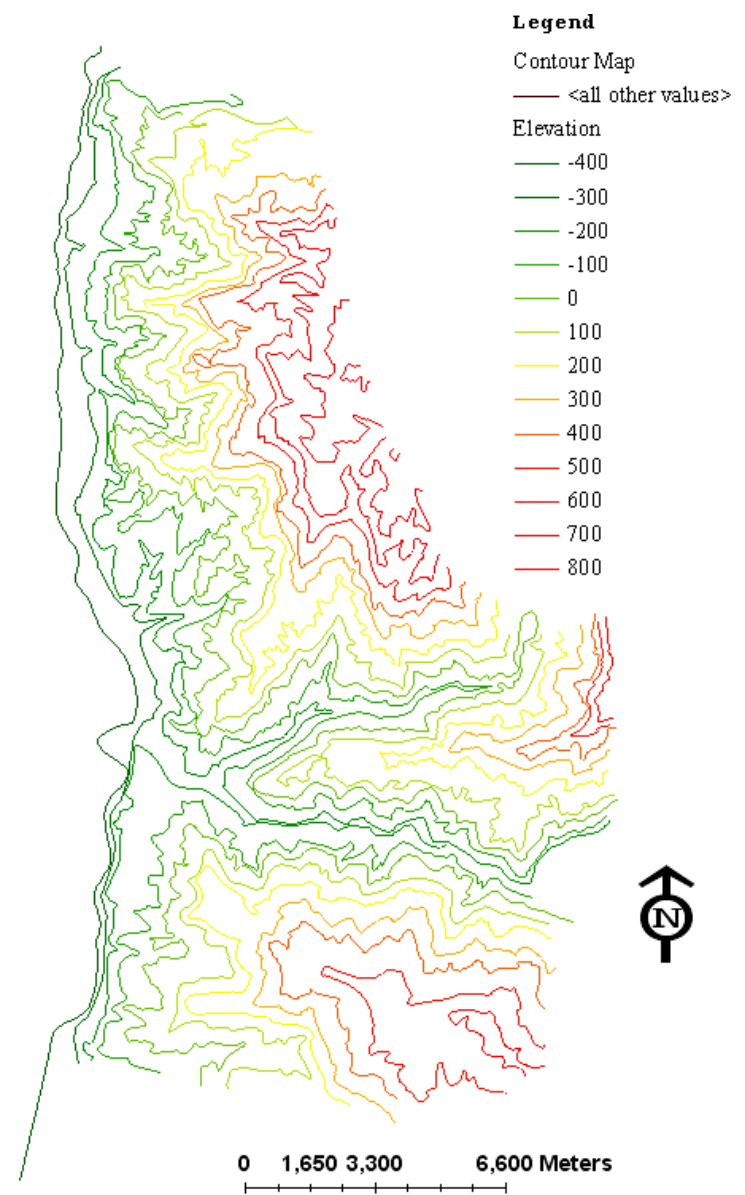

Figure 3. Al Mujib reserve contour map (RSCN) (Elevation in meters).

However, such huge change in elevation within a limited area imposes challenges for developing and managing the reserve, where certain areas are not easily accessible due to their steep slopes and rough topography. On the other hand, this altitude variability at one side represents an attractive factor for the reserve where different ecosystems and environmental conditions exist at different areas of the reserve which makes the reserve home for various types of rare fauna and flora that should be documented and regularly monitored.

In order to understand the behavior and characteristics of any Sustainable Ecotourism Management Plan process in the reserve, it is very important first to assess a complete image of the topography of the study area. GIS analysis is performed using $3 \mathrm{D}$ surface modeling to better understand 
the reserve's terrain topography. For this purpose, a GIS layer of 3D TIN continuous surface of the reserve area is produced as shown in Figure 4 and Figure 5.

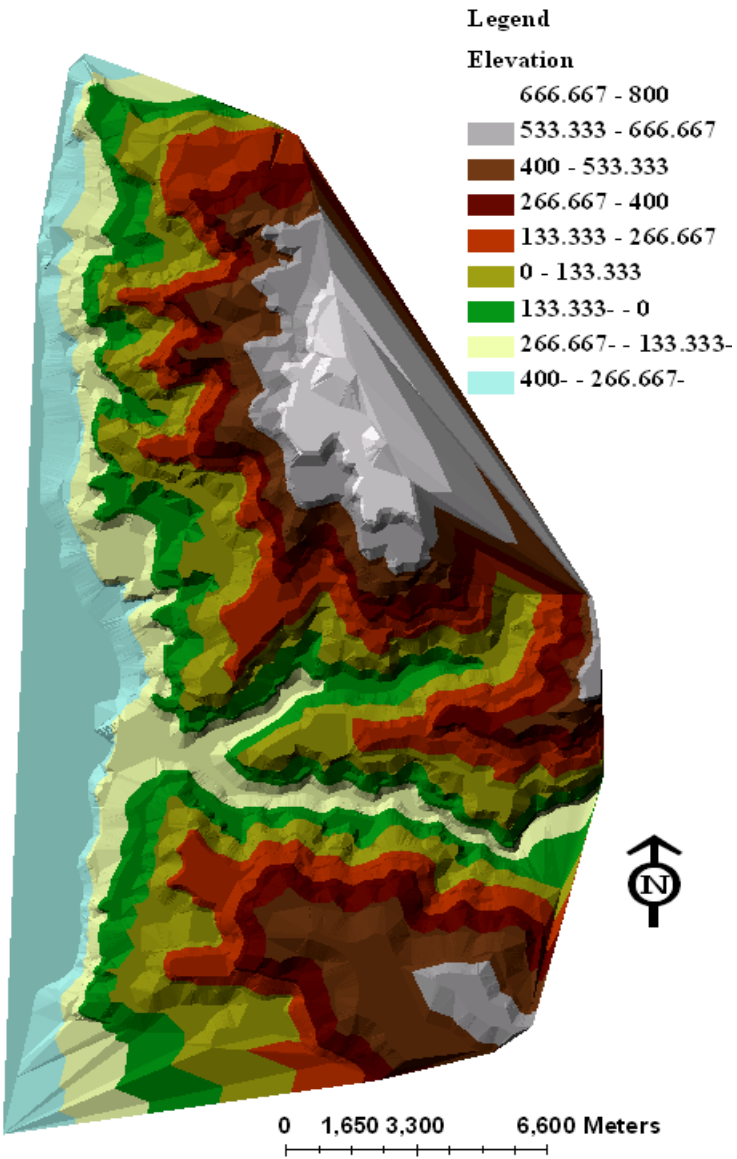

Figure 4. Al Mujib reserve TIN surface (Elevation in meters)

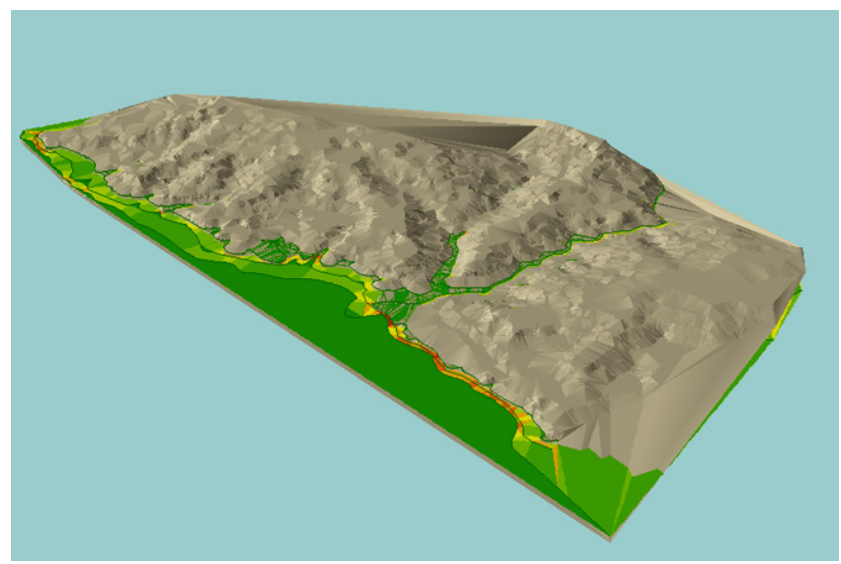

Figure 5. 3D GIS topography surface

3D TIN continuous surface modelling provides an opportunity to study and forecast flash flood areas in a consequence of this dramatic change in altitude and the presence of several flowing rivers. In addition it helps to determine visual impact areas and prioritize risks. This while the topographical nature of a given terrain plays a major role in the organization, size and distribution of any ecotourism activities within the reserve boundary of the planning process. The TIN (Triangulated Irregular Network) created for the Slope Analysis map was utilized to develop a viewshed analysis of the reserve. The goal of the analysis is to understand how much of the landscape can be seen to better understand scenic preservation strategies.

The digital elevation model (DEM) produced shows clearly the surface topography of the reserve and the large variation in elevation for mountains, valleys (wadis) and other intermediate topographical features ending with the Dead Sea as the lowest elevation surface. The Dead Sea surface can be of great benefit, for example, for water engineers and hydrologists to delineate catchments areas and for surface water modeling.

Furthermore, to identify the variable slope categories existing within the reserve with the steepest slopes a slope layer is created based on the contour and TIN surfaces shown in Figure 6 (looking from the south-west direction). The slope surface layer is highlighted in red color. Clear identification of such steep slope areas is extremely important for the following reasons:

1-. For safety purposes where such areas should be clearly marked and all necessary safety measures (e.g., guardrails) need to be provided.

2-. Such steep slope areas are usually witnessing an enormous soil erosion activity and the precise identification of such locations can help in taking all necessary precautions to reduce such soil loss.

3-. In Al Mujib reserve more hiking adventures can be developed due to its distinguished topography and natural elements making it the best place for Hiking. Figure 7 presents a GIS layer showing the major hiking trails in Al Mujib reserve. From this layer it is clear that hiking in Al Mujib may involve walking for long distances in a variable topography, climbing/descending cliffs and cascades, and swimming in the existing water channels. Such trails extend for few kilometers; some of these trails can extend from the farthest eastern side of the reserve to end at the Dead Sea shore covering a wide range of altitude.

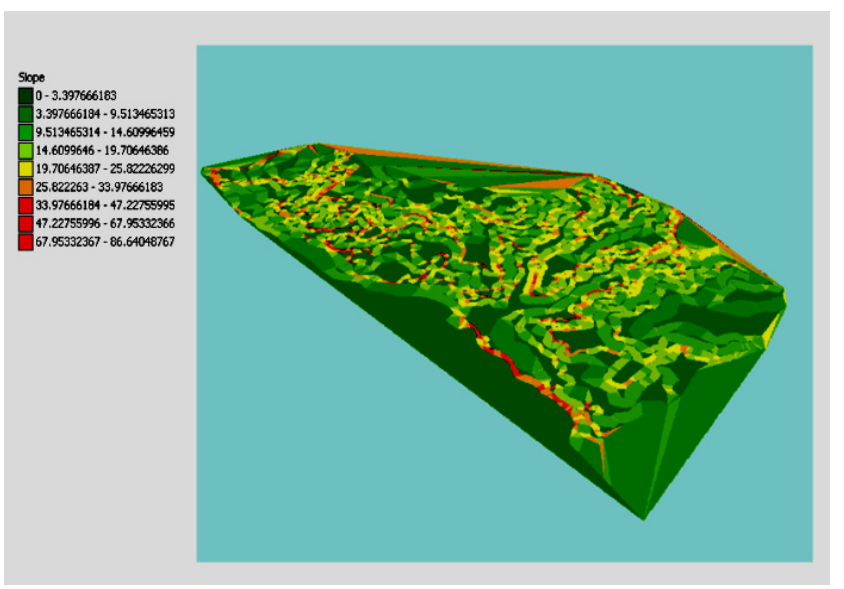

Figure 6. Slope surface analysis in GIS (in degrees) 


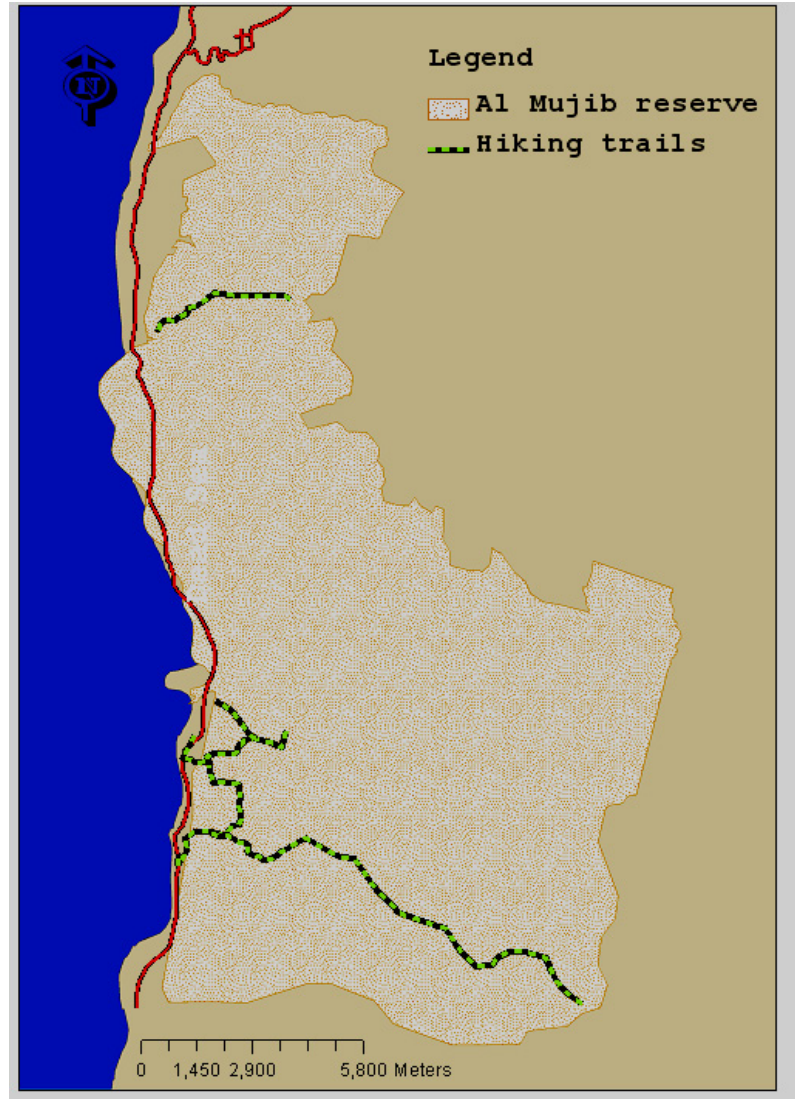

Figure 7. GIS layer showing the major hiking trails in Al Mujib reserve (Source: RSCN).

\subsection{Enhancement of the Biodiversity System in Al Mujib Reserve}

To present the ecological importance of Al Mujib reserve and based on the results of a detailed survey for Al Mujib reserve biodiversity performed by the RSCN, a GIS map is created to document landscape and the different biodiversity system components in Al Mujib reserve (Figure 8). Analytically, this GIS map shows:-

- The main fauna spatial distribution, the main birds' congregation locations in Al Mujib reserve. These are mostly located at the eastern and northern territories that are characterized with a mountainous topographical nature. Such active bird existence in the reserve can be referred to the fact that the reserve is an important immigration stop point for birds traveling between different continents.

- The spatial locations of other different fauna categories including carnivores, raptors and roe deer.

As can be seen in Figure 8, the reserve is mainly divided into five vegetation types namely: Mediterranean (extended over small areas at the eastern edge of the reserve), Iranoturranian (most dominant vegetation cover at the middle), Aquatic Vegetation, Tropical, Saline (dominant at the western edge of the reserve nearby the Dead Sea shore). Furthermore, Figure 8 shows the spatial distribution of some of the important flora species (six types are shown: Kickxia judaica, Ophioglosum polyphyllum, Polygomum argyrocoleum, Withania obtusifolia, Orchid and Palm of which the first four are considered new flora in Jordan[29] Table 3.

Table 3. Al Mujib reserve Fauna and Flora analysis in GIS

\begin{tabular}{|c|c|}
\hline Map Title & Data Layer \\
\hline Fauna & Carnivores, Raptors, Roe deer and Birds. \\
\hline Flora & $\begin{array}{c}\text { Kickxia judaica, Ophioglosum polyphyllum, } \\
\text { Polygomum argyrocoleum, Withania obtusifolia, } \\
\text { Orchid and Palm. }\end{array}$ \\
\hline
\end{tabular}

Even though such map represents a rich source of information for the biodiversity system in the reserve, the need still exists for more field surveys to collect more information about the many flora and fauna location and categories in the reserve. This will provide a large information source of which detailed GIS maps should be produced for different natural features to be used later in different types of analysis such as monitoring the temporal change in the biodiversity system condition.

For example, from this layer, queries can be directed to the database to extract information and relationships. Overlay analysis to test interrelations between different layers, proximity and buffering analysis (Figure 9 shows example buffering area for flora with 300 meters protection area) are among the possible analysis schemes. Though, multi-criteria analysis can be also used for site selection related to natural or man-made reserve features.

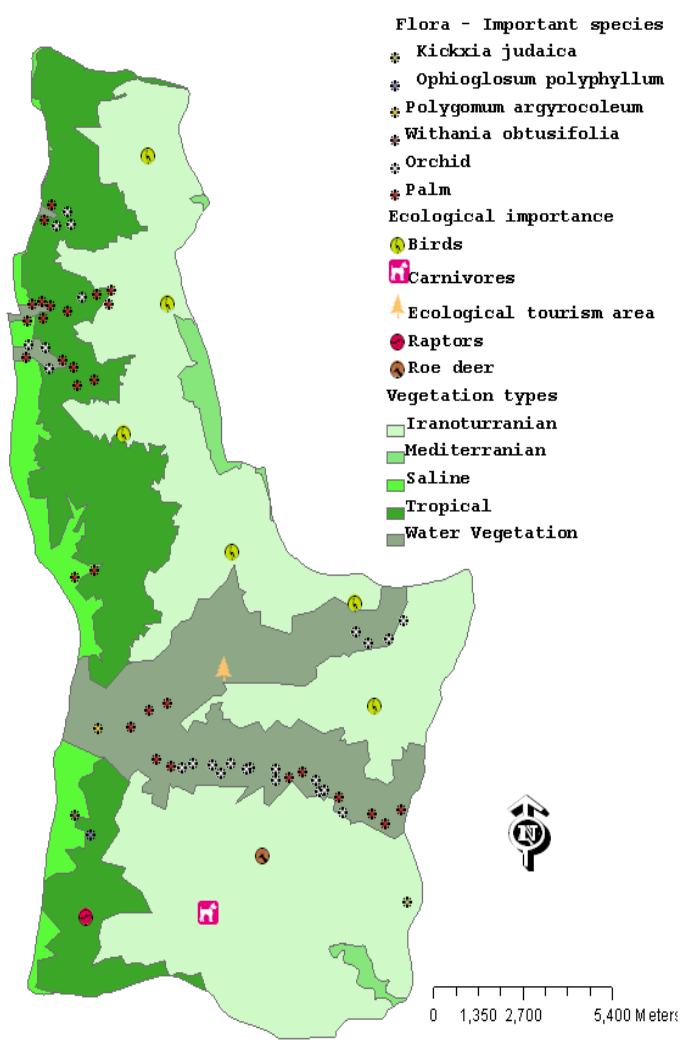

Figure 8. Fauna, flora and ecological importance of Al Mujib reserve 


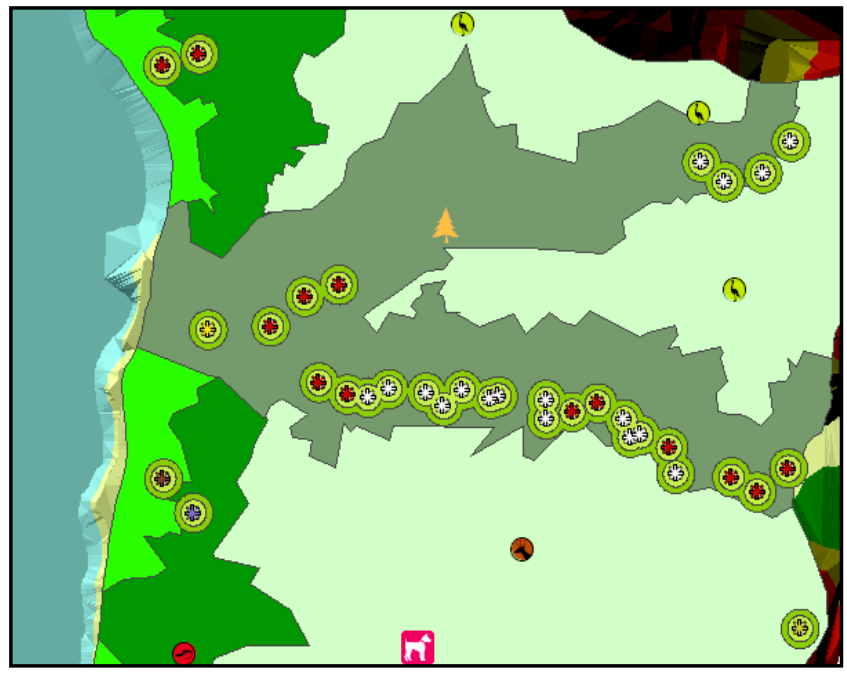

Figure 9. Flora buffering example ( $300 \mathrm{~m}$ protection area)

\subsection{Discussion: Development of Strategy and Regulations for a Sustainable Ecotourism Management Plan for Al Mujib Reserve}

Tourism is of vital importance for national economy of Jordan. The structure of the tourism industry in Jordan is divided into four main bodies; namely, public sector, public/private partnership, private sector and NGOs. Tourism is the third most important sector for generating income after the mining industries of Potash and Phosphates and the remittances by Jordanian expatriates [15]. It contributes $17.4 \%$ to the GDP, accounted for $48.3 \%$ of the export of goods and $80.8 \%$ of the exports of services[29,15].

Between 2004 and 2009, Jordan has achieved dramatic progress in terms of tourism receipts. The predicted tourist arrival in Jordan (2006 - 2010), was 3.2 millions in 2006, with 6.5 annual average growths (\% 2001-2006). The number of tourists to Jordan for the year 2009 was 3.79 million[20]. In 2010 the tourist arrivals was 6.5 million, with $10 \%$ annual average growths (2006-2010). Between 2004 and 2009 hotels increased by $4.8 \%$; travel agencies increased by $36.2 \%$, restaurants increased by $72.5 \%$, and tourist guides increased by $42.2 \%$ [15]. The tourism development in different activities in Jordan 2004-2009, confirm the importance of tourism as a major economic supporter and shows that the sector is in development.

Jordan's National Tourism Strategy 2004-2010 outlines the steps for doubling the Kingdom's tourism economy by 2010 using an integrated, value-chain approach involving government facilitation and investment in partnership with the private sector. The strategy targets the following priority niche markets: Cultural Heritage (mainly Archaeology), religious and eco-tourism, health and wellbeing, adventure, meetings, incentives, conferences, and events (MICE), The Jordan National Tourism Strategy of 2004 to 2010 has proven successful, according to Euromonitor International's report "Travel and Tourism in Jordan"(http://www.euromon itor.com), with the goals of doubling GDP to JOD 1.9 billion
(US \$2.7 billion), generating JOD 408 million (\$576 million) in tax revenue and supporting 308,000 jobs nationally, and achieved a year early.

However, the average length of a tourist visit in Jordan is 4.3 nights [20], and is related to a seasonal demand. This is one of the criteria that necessitate other types of sustainable development resources for local communities dependent on tourism, especially with the discontinued pattern of tourist occupancy and length of the high season. Ecotourism in Jordan, however, deals with responsible travel for the principal purpose of visiting not only nature but historical areas, antiquities and the living culture in the mean time [14].

Although a new national strategy was introduced in 2010, there is still a need for adopting a policy providing operational definitions and guidelines for ecotourism and the natural reserves. This can start by dividing the nature reserve into two main classifications, highly protected and sustainably managed. In this strategy the following actions should be taken in to consideration for the reserve:-

- To conduct comprehensive land use plan and create Buffer zones using GIS system, in order to protect the rare and endangered species and wildlife and provide an enough and suitable environment for wild plants and animals, and for future expansion of the nature reserve. This comprehensive plan should include agriculture, forestry, animal husbandry, community development and community capacity buildings. Development of local community needs should be given higher priorities, but any single resources development oriented projects should not be stopped and allowed in the reserve area.

- Strengthening capacity building. There is a need for conducting more activities on community development and capacity building. There is a need to organize kinds of short and long term training courses, workshops or study tours relative to the topic of management of the reserve for the local community such as: community water, fauna and flora, co-management concept, advanced technical training courses. This will make more opportunities to select some qualified people to participate in the preservation process. The following are some recommendations for integrating community benefits to participatory management:

a) Coordination between the private and public sectors, to enhance the partnership between the two sectors which is essential for a sustainable marketing strategy.

b) Except for new jobs and incomes, there is a need to demonstrate a mechanism to increase local participation in the benefits of biodiversity conservation to ensure generating revenues toward conservation of biologically rich areas. This while contributions of ecotourism, actually, should include raising local awareness about the value of biological resources.

c) Ensuring sufficient training of staff when 
conducting activities majored in community development, with the aim to develop the current policies and regulations relative to management and protection of the nature reserve and community resources.

d) To create community patrols' management system. This system will assist to develop and improve award and punish system for illegal trees felling, poaching and other offences detrimental for local ecology. This system will also support applying the regulations for water management among local community's rules and country's policies, laws and regulations relative to the reserve.

e) To determine the staff's roles and responsibilities at the nature reserve. The key issue is to establish community development and technical extension association and environmental offices and stations at the nature reserve according to the existing water and dry trails, in order to define and determine the staff's responsibility at each part of the reserve. Transforming them from the pure patrol to implementing to supervision, instruction, advice for community development, will assist to create a number of personals that should be appointed only to conduct community development and natural resources management.

- Action plan should be taken to create and develop management of community water, fauna and flora resources by RSCN. This can include:

a) Establishing by RSCN community based water management association mainly composed of different stakeholders from the local community.

b) Establishing a mechanism to strengthen exchange and communication between RSCN reserve management and nearby communities.

c) Implying by RSCN appropriate regulations and measures for management of community water based on policies, laws and regulations, according to the particularity of local Jordanian traditional custom.

d) Use digital and social media platforms to propagate policies, laws and regulations relative to environmental protection, water resources and nature reserve management in community, even respecting the diversity of visitors. This can be aided by multi-lingual presentations, publications, and websites. As recommended by the International Cultural Tourism Charter. This offers a wider distribution of benefits and relieving pressure on more popular places by encouraging visitors to experience the wider natural heritage of a region or locality.

- Monitoring environmental conditions of the reserves; periodical check, supervision and local community visit and meeting system should be established for the reserve staff.

- The use and application of other supported digital spatial documentation techniques, like 3D laser scanning, which represents today the most advanced technology available for measuring and documenting objects, structures and especially for irregular surfaces as landscape. In fact, 3D laser scanning technology is particularly well suited for recording landscapes formation, especially when making detailed inventory records that need to be accomplished rapidly, while such objects are extremely difficult to documented using graphic techniques [13]. These ? 3D models are an extremely useful tools to make a representation of a complex object and have a remarkable impact on the public observing 3D products in nature interpretation halls and web sites. 3D digital photo-models in combination with multispectral imagery such as visible, near-infrared, and thermal infrared imagery in combination with terrestrial laser scanning can be used to assess and monitor the state of preservation as well as to study, visualize, analyze the weathering damage. In Addition, 3D Laser scanner can be considered as one of the most effective instrument for landscape monitoring (3D monitoring). Three-dimensional risk mapping for anti-disaster recording in cultural heritage [26], will provide helpful records in monitoring the natural reserves. On the other hand, the scanned data are tied to real world coordinates which makes it possible to be used for GIS or spatial statistical analysis.

\section{Conclusion}

The long-term protection and conservation of natural reserves, including their bio-physical and environmental contexts can play a vital role in social, economic, cultural and eco-tourism development policies in a developing country like Jordan. However, for-developing ecotourism a positive economic and environmental tool in developing countries like Jordan, conservation of the biological heritage requires strategies and policies that promote responsible nature tourism development, broad-based and active local participation in its benefits.

It is clear that the long-term preservation of this unique reserve is extremely challenging. The need for accurate and timely information is crucial for safety and the reserve resource protection. To achieve sustainable development that balances the needs of the visitors and the local community with the needs of reserve, a multi-disciplinary approach and team is needed. For example, for a systematic documentation of the reserve, a variety of scientific tools can be utilized now like; the accurate 3D recording with terrestrial laser scanning (TLS), close range photogrammetry, multispectral imaging, thermography, XRF, XRD, and polarization microscopy can all be utilized for such purpose. In addition to pathological studies that assist in the integration of the results and guide the recommendations, specially for the sharp edges and cliffs 
of different altitudes of Paleozoic sandstone mountains at lower altitudes and of Mesozoic limestone at higher altitudes which dominate the area.

Moreover, enhancing the reserve physical legacy could further arouse locals and visitors interest in the perception of natural reserve sustainability, though allowing it to become a source of information for future generations and a document of nation history.

The general approach presented in this paper can be considered as a baseline for other reserves in Jordan. However, any conservation plan for the reserve should be an active plan, allowing monitoring and updating of information over time. A strategy based on practical testing, continual monitoring and preventive care should take place in order to develop the appropriate practice for each type of risk. However, the paper here discusses the important issue of enhancement of the natural reserves in Jordan by further implementing GIS documentation approach, where we can guarantee a production of an integrated and sustainable ecotourism management plan for the natural reserves.

Taking Al Mujib reserve as a case study, a number of GIS spatial layers were created to document, explain and assist the reserve's landscape, biodiversity and infrastructure systems that can be used. The GIS database, Table 2, for Al Mujib reserve started with mapping the spatial location and extent of the reserve followed by the accessibility analysis to and within the reserve to assess the current status of the transportation system serving the reserve. Table 4 finally shows suggested GIS data layers that need to be implemented.

Table 4. Al Mujib reserve suggested analysis in GIS

\begin{tabular}{|c|c|}
\hline Map Title & Data Layer \\
\hline Hydrology & $\begin{array}{c}\text { Drainage, Hydro Spread, } \\
\text { Hillshade,Surface Water Basins }\end{array}$ \\
\hline Mineral Resources & NRA Mining Blocks \\
\hline Fault Lines & Fault Lines \\
\hline Land Sensitivity & Land Sens \\
\hline Agricultural Suitable Soils & All Agricultural Suitable Soils \\
\hline $\begin{array}{c}\text { Views from Scenic Roads } \\
\text { Landmarks }\end{array}$ & Views from Scenic Roads \\
\hline Forest Suitable Soils & Forest Suitable Soils \\
\hline Archeological Sites & Monument Sites \\
\hline
\end{tabular}

It can be concluded that, to enhance the accessibility level, there is a need to establish more roads to connect the highways surrounding the reserve with different parts of the reserve. A ring road that goes all the way around the reserve ensuring an enjoyable observatory for the reserve's landscape will be an attractive factor in any development plan.

To investigate the reserve's variable topography, a series of GIS layers (Contour map and TIN elevation surface) were created, besides producing a slope layer to delineate the steep slopes locations. Such layers present a clear image about the reserve's landscape altitude variably and its potential in creating a rich and rare biodiversity system of fauna and flora.

This is clear from the comprehensive GIS layer created for documenting different types of fauna, flora and other ecological species Fig 8, Table 3 . Such layer showing the spatial distribution of these species and how such locations are related to the reserve landscape features should be considered as the key policy for any management and conservation plan of the reserve. The created GIS layer document the different hiking trails in the reserve, some of these can extend from the farthest eastern side of the reserve to end at the Dead Sea shore covering a wide range of altitude.

Any eco-tourism management plan of the reserve must deal and agree with the adequate handling of all the natural resources found within the reserve area from biophysical and the human aspect, and in relation to community development. This database can be used as a model for the other natural reserves in Jordan.

However this database still needs field work to collect more attributes, as it is an important source of information for the reserve that can be used for various types of studies, analysis and monitoring. For example the data obtained from RSCN provides a general overview of vegetation zones and types. More accurately identifying sensitive areas of flora and fauna will more clearly delineate areas that should be protected from any development. In the case of water resources from wadis more detailed topography will assist in a more accurate delineation of water sheds to balance growth and water supply.

In order to develop a detailed Integrated Environmental Improvement Plan (IEIP) there is a need to conduct more research on monitoring water supply, road networks and the wildlife, infrastructure improvements including the design of other necessary footpaths. A proper water management can assist to control the negative impacts, preventing costly degradation repair and in turn improving the reserve sustainability. The developed and updated GIS system can be used for these different applications in managing sustainable natural reserve and nature conservation, preparation of a field guide for the protection and preservation of the reserve, as well as environmental impact assessment (EIA) that can be conventionally used as a tool for permitting any new project on and around the site especially with the huge number of the five stars tourism construction at the Dead Sea.

This special documentation system for Al Mujib reserve is supposed to be considered as the start for coming steps and to expand the scope of this work to develop a national GIS documentation system for the reserves' network in Jordan by applying appropriate technologies, and exchange of information from other countries with successful experience in sustainable policies. In any new national eco-tourism strategy the following actions should be taken into consideration:

- There is a need for dividing the nature reserve into 
two main classifications, highly protected and sustainably managed by RSCN.

- To conduct comprehensive land use plan and define Buffer zones using GIS system.

- Strengthening capacity building and determination of the staff's roles and responsibilities at the nature reserve and conducting more activities on community development.

- Development of a management of community water resources by RSCN .

- Monitoring of the environmental conditions of the reserve with the support of GIS and 3D laser scanning.

- New creative events and routes and other eco-entertainment and eco-edutainment packages should be developed in order to satisfy a wider spectrum of visitors and tourists. These new creative events and routes can assist in extending the stay of tourists, such as nightlife adventure activities and other optional tours, not included in the package tour programs.

\section{Acknowledgments}

The authors would like to express their deep thanks for the Royal Society for Conservation of Nature (RSCN) for their cooperation and continuous help through providing some basic shapefiles that were used in creating and analyzing different GIS spatial layers in this paper.

\section{REFERENCES}

[1] Al-Hakawati website, Mujib Nature Reserve, http://www.alhakawati.net/english/Environment/env24.asp, accessed July 2009.

[2] Al-Hanbali A., Al-Bilbisi H. and Kondoh A., 2005. The environmental problem of the Dead Sea using remote sensing and GIS techniques. The 11th CEReS International Symposium on Re http://www2.cr.chiba-u.jp/symp2005/documents/Postersessi on/p017_AAlHanbali_paper.pdf

[3] Al-Eisawi, 1996 D.M. Al-Eisawi, Vegetation of Jordan., UNESCO-Regional Office for Science and Technology for the Arab States, Cairo (1996) pp. 266.

[4] Sharaf Al-kheder, Naif Haddad, Leen Fakhoury, Suha Baqaen , 2009. A GIS Analysis of the Impact of Modern Practices and Polices on the Urban Heritage of Irbid/Jordan. Cities, 26( 2), pp. 81-92

[5] Atiat, Taysir M., A Nabataean Sanctuary at al-Mujib Nature Reserve: a Preliminary Notice, Levant, Volume 37, Number 1, June 2005 , pp. 163-168(6)

[6] Atlas Travel and Tourist Agency (ATTA) website, Mujib Wildlife Reserve, http://www.atlastours.net/jordan/mujib.ht $\mathrm{ml}$, accessed July 2009.
[7] Berendse F., Chamberlain D., Kleijn D., and Schekkermann H., 2004. Declining biodiversity in agricultural landscapes and the effectiveness of agri-environmental schemes. Ambio, 8, pp. 499-502.

[8] BirdLife International, BirdLife's online World Bird Database: the site for bird conservation. Version 2.1. Cambridge, UK: BirdLife International. Available: http://www.birdlife.org accessed August, 2009.

[9] Breceda A., Arriaga L., Bojorquez L. and Rodriguez M. 2005. Defining critical areas for conservation and restoration in a Mexican biosphere reserve: a case study. Natural Areas Journal, 25(2), pp. 123-129.

[10] DellaSala D. A., Staus N. L. , Strittholt J. R. , Hackman A., and Iacobelli A., 2001. An updated protected areas database for the United States and Canada. Natural Areas Journal, 21(2), pp. 124-135.

[11] Elliott C. and Udovč A., 2005. Nature conservation and spatial planning in Slovenia: continuity in transition. Land Use Policy, 22 (3), pp. 265-276.

[12] El-Sherif A. S., 2009. Managing Natural Reserves Using GIS/RS, Case study: Sabah Al Ahmad natural reserve, Kuwait. Conference on land degradation in dry environments, 8-14 March, Kuwait. http://cldde.kuniv.edu/Abstract/29-Ah med_Saad.doc.

[13] Haddad, N. 2007. Towards creating a dialogue between the specialized technician and non technician users of the3D laser scanner, in: Proceedings of CIPA XXIth International Symposium, 01-06 October, Athens, Greece, 350-355.

[14] Haddad, N., Waheeb, M. and Fakhoury, L., 2009. The Baptism archaeological site of Bethany beyond Jordan: Towards an assessment for a management plan. Tourism and Hospitality Planning and Development, 6 (3), 173-190.

[15] Harahsheh, S., 2009 An evaluation of the image of the Hashemite Kingdom of Jordan in the British and Swedish markets and the implications for marketing the country as a tourism destination, Bournemouth University, United Kingdom.

[16] Hudaib M., Mohammad M., Bustanji Y., Tayyem R., Yousef M., Abuirjeie M., Aburjai T., 2008. Ethnopharmacological survey of medicinal plants in Jordan, Mujib Nature Reserve and surrounding area. Journal of Ethnopharmacology, 120, pp. 63-71.

te Sensing. Chiba University, Chiba, Japan.

[17] Jones-Walters L., 2008. Biodiversity in multifunctional landscapes. Journal for Nature Conservation, 16, pp. $117-119$

[18] Jordan Jubilee website, Nature reserves in Jordan: Wadi Mujib, http://www.jordanjubilee.com/outdoors/wadimujib.ht m, accessed August 2011

[19] Jordan National Tourism Strategy, 2004-2010. Amman: Ministry of Tourism and Antiquities( MOTA.

[20] Ministry of Tourism and Antiquities (MOTA) 2010, http://www.tourism.jo/inside/Main.asp.

[21] Muller S., 2002. Diversity of management practices required to ensure conservation of rare and locally threatened plant species in grasslands: A case study at a regional scale (Lorraine, France). Biodiversity and Conservation, 11, pp. $1173-1184$. 
[22] National Capacity Self Assessment for Global Environmental Management (NCSA)- Jordan, Environmental Profile of Jordan, 2006. Ministry of Environment, Amman- Jordan, http://www.environment.gov.jo/Jordan_environmental_profi le_2006.pdf.

[23] Nichol J. E., GIS for Nature Reserves Management in Singapore. In Sustainable NaturalResource Management and Spatial Planning in Developing Countries: Geo-Information Technology Perspective. Selected Papers Presented at the International Seminar on Resource Management and Spatial Planning in Developing Countries: Geo-Information Technology Perspective, Bandar Seri Begawan, 22-25 April 1992, edited by Josefa S. Edralin and Tin Seong Kam, 157-167. Nagoya, Japan: United Nations Centre for Regional Development, 1993.

[24] Sawarieh A., Chen C. , Beinhorn M. , Kolditz O., Salameh E. and Hötzl H., 2009. A GIS based model for groundwater flow and heat transport in Zarqa Ma' in - Jiza areas - central Jordan. http://www.ipcri.org/watconf/papers/sawarieh.pdf, accessed June 2009.

[25] Santana Quintero, M., Van Genechten, B. 2007. Three-dimensional risk mapping for anti-disaster recording of historic buildings, In: Proceedings of CIPA XXI th International Symposium, 01-06 October, Athens, Greece,
325-330.

[26] The International Ecotourism Society (TIES) website. http://www.ecotourism.org/index2.php?whatis-ecotourism, accessed May, 2009.

[27] UNESCO World Heritage Centre website, Mujib Nature Reserve, http://whc.unesco.org/en/tentativelists/5158/, accessed August, 2009.

[28] Wanghao and Tsering, D., 2002. Tibet Nature Reserve GIS Database and GIS Introductory Training in Lhasa, Tibet. World Wildlife Fund (WWF) website http://www.wwfchina.org/english/downloads/Tibet/GIS\%20 Trainin\%20Report1.doc, accessed May 2009.

[29] UNWTO, 2009. Handbook on tourism destination branding. Madrid: Unwto.

[30] Weibull A., O“stman O*., and Granquvist A., 2003. Species richness in agro-ecosystems: The effect of landscape, habitat and farm management. Biodiversity and Conservation, 12, pp. 1335-1355R. F. Voss, J. Clarke. Algorithmic Musical Composition, Silver Burdett Press, Londyn, 1986.

[31] World Commission on Environment and Development, 1987. Our Common Future, Report of the World Commission on Environment and Development. 